\title{
Antibacterial Potential of Quercetin against IBD Bacterial Isolates and Cytotoxicity against Colorectal Cancer
}

\author{
Sanjay Mishra',2,*, Damita Cota' ${ }^{1}$, Sunil Satyappa Jalalpure ${ }^{1,2}$ \\ 'Department of Natural Product Research, KAHER's Dr. Prabhakar Kore Basic Science Research Center, KLE Academy of Higher Education and Research, \\ Nehru Nagar, Belagavi, Karnataka, INDIA. \\ 2Department of Pharmaceutics, KAHER's College of Pharmacy, Belagavi, KLE Academy of Higher Education and Research, Nehru Nagar, Belagavi, Karnataka, INDIA.
}

\begin{abstract}
Background: Quercetin is known for its vast pharmacological activities in recent years. It has shown beneficial effects in animal models of colitis. Purpose: The effectiveness of quercetin in human IBD is limited. Results from these pre-clinical studies indicate an opportunity for developing anti-colitic polyphenol treatments. Methods: In the present study. Quercetin was evaluated for its antimicrobial potential against clinical isolates of IBD patients (HM95, HM233, HM251, HM615). Cytotoxicity was determined against human colorectal adenocarcinoma cells (Caco2, COLO.205, HT.29), whereas, cytocompatibility against normal rat intestinal epithelial (IEC-6). Results: It showed an MIC value of $5 \mathrm{mg} / \mathrm{mL}$ and MBC value of $10 \mathrm{mg} / \mathrm{Ml}$ against all the four bacterial isolates. A dose dependent response was observed against the cell lines. Conclusion: Antibacterial activity of Quercetin was found against the bacterial isolates from CD and UC patients used in the study. Cytotoxity was observed against colorectal cancer cells with minimal effect on normal cells. However, further investigations are required to understand its precise mechanism.

Key words: Polyphenol, Quercetin, Cytotoxicity, Inflammatory bowel disease, Colorectal cancer.
\end{abstract}

\section{INTRODUCTION}

Inflammatory Bowel Disease (IBD) comprises of chronic, relapsing, inflammatory disorders of the gastrointestinal tract which includes Ulcerative Colitis (UC) and Crohn's Disease (CD) ${ }^{[1]}$ It is characterized by diarrhoea, rectal bleeding, the urgency to have bowel movements, abdominal cramps, fever and weight loss. ${ }^{[2,3]}$

IBD patients are at a greater risk of colorectal cancer due to prolonged exposure to chronic inflammation and immunosuppressive therapies. ${ }^{[4]}$ The colonic mucosa of Crohn's disease and mucosa of colon cancers specimens contain relatively abundant E. coli, compared to normal mucosa. These E. coli express hemagglutinins and adhere to intestinal epithelial cells are found in CD and UC patients. ${ }^{[5]}$

In the past IBD was considered as a disease of the western population, however new epidemiological studies in the last decade suggest rise in cases throughout the world including the developing countries in Asia and Africa. ${ }^{[6]}$ Its incidence and prevalence is increasing in India and estimated to have a high disease burden in the world with few resources to manage it. ${ }^{[7]}$

Quercetin has shown beneficial effects in animal models of inflammatory bowel disease, working through inflammatory pathways, oxidative stress reduction and altering gut microbiota composition. ${ }^{[8,9]}$ It has also shown efficacy against human colon cancer cell lines. Although evidence for the effectiveness of polyphenols for IBD in humans remains very limited, results from these pre-clinical studies indicate an opportunity for developing anti-colitic polyphenol treatments. ${ }^{[10]}$ In this study we aim at assessing the antibacterial activity of Quercetin against isolated four E. coli strains from inflammatory bowel disease patients, further evaluate cytotoxicity against 3 colorectal cancer cell lines.

\section{MATERIALS AND METHODS}

\section{Test Materials and sample preparation}

The polyphenol, Quercetin (R035PO) was obtained as gift samples from Pharmanza Herbal Pvt. Ltd.

\section{Antibacterial activity}

Bacterial isolates - Escherichia coli HM95 (AIEC), Escherichia coli HM615 (colonic mucosa associated. E. coli), Escherichia coli HM233 and Escherichia coli HM251 (colonic mucus associated patient strains) were received under Material Transfer Agreement with University of Liverpool, United Kingdom. The bacterial isolates were subcultured on MacConkey agar (HiMedia) plates and incubated aerobically at $37^{\circ} \mathrm{C}$. The antibacterial activity of Quercetin was evaluated by agar well diffusion method and MIC (detected by broth dilution method) as previously reported with minor modifications. ${ }^{[11]}$

\section{Determination of cytotoxicity and cytocompatibility}

Human colorectal adenocarcinoma cells (Caco2, COLO.205 , HT.29) and normal rat intestinal epithelial cells (IEC-6) were obtained from National Center for Cell Sciences, Pune-India. The cells were maintained in Dulbecco's Modified Eagle's Medium (DMEM) with two $\mathrm{mM}$ L-glutamine, $100 \mathrm{IU} / \mathrm{ml}$ penicillin, $100 \mu \mathrm{g} / \mathrm{ml}$ streptomycin and supplemented with 10\% FBS procured from Gibco Life Technologies, 
Bangalore-India. Viable cell suspension $50 \mu \mathrm{l}$ with a density of $1 \times 10^{5}$ cells/ml (determined by Trypan blue exclusion method) was seeded into each well in a 96 well micro titre plate and final volume made upto 150 $\mu \mathrm{l}$ with DMEM media. Test materials were diluted in DMEM media to obtain different concentrations. $100 \mu \mathrm{l}$ of Quercetin $(400-6.25 \mu \mathrm{g} / \mathrm{ml})$ was added to the wells followed by incubation for $48 \mathrm{~h}$ in the presence of $5 \% \mathrm{CO}_{2}$ at $37^{\circ} \mathrm{C}$ into $\mathrm{CO}_{2}$ incubator. After the incubation period, $20 \mu \mathrm{l}$ of MTT reagent (3 - (4, 5-dimethylthiazol- 2 - yl)-2, 5-diphenyltetrazolium bromide, $5 \mathrm{mg} / \mathrm{ml}$ in PBS) procured from HiMedia laboratories, was added to each well following $4 \mathrm{~h}$ incubation in dark. The supernatant was removed without disturbing the precipitated Formazan crystals. Formed crystals were dissolved by addition of $100 \mu \mathrm{l}$ of DMSO and optical density (OD) was calculated at a wavelength of $492 \mathrm{~nm}$. Cell-viability assays were conducted as per previously reported standard procedure. ${ }^{[12]}$ The study was performed in triplicates and percent cell viability was calculated using equation -

Percent cell viability $=\frac{\text { OD of test material }}{\text { OD of control }} \times 100$

\section{Statistical analysis}

Statistical analysis was carried out using Graph Pad Prism 5.0 software.

\section{RESULTS AND DISCUSSION}

\section{Antibacterial activity}

The results of antibacterial effect of Quercetin against the four IBD clinical isolates are listed in Table 1. Quercetin is shown to modify bacterial diversity in Citrobacter rodentium induced colitis mouse model. Wherein it enhanced bacterial populations of Bacteroids, Bifidobacterium, lactobacilli and Clostridia and reduced Enterococcus and Fusobacterium. In this study quercetin showed MIC value of 10 $\mathrm{mg} / \mathrm{mL}$ and $\mathrm{MBC}$ value of $5 \mathrm{mg} / \mathrm{mL}$, against the four IBD strains used in the study. The highest zone of inhibition of $24.33 \mathrm{~mm}$ was observed against HM233. Use of antibiotics in IBD management has seen severe side effects and drug resistance cases due to need for prolonged or recurrent treatment. ${ }^{[13]}$ This has stimulated the need for discovery of newer substances from natural origin, including medicinal plants as antimicrobial substances to attain efficacy and better tolerability. There is increasing evidence that the mucosa-associated microbiota, may be essential in the pathogenesis of the inflammatory bowel diseases: ulcerative colitis and Crohn's Disease. ${ }^{[5]}$ However, no study data has been published showing the antimicrobial activity of quercetin on IBD strains till date. Although a recent study demonstrated the bacteriostatic role of quercetin and the results of the study suggest that quercetin has potential as an alternative antibiotic feed additive in animal production. ${ }^{[14]}$

\section{Cytotoxicity of Quercetin against Colorectal cancer cell lines}

The percent cell viability decreased on $48 \mathrm{~h}$ exposure of colon cancer cells to quercetin at concentrations ranging from $400-12.5 \mu \mathrm{g} / \mathrm{ml}$

Table 1: Antibacterial activity of Quercetin against Clinical isolates of Crohns disease.

\begin{tabular}{|c|c|c|c|}
\hline $\begin{array}{c}\text { Bacterial } \\
\text { strains }\end{array}$ & MIC $(\mathbf{m g} / \mathbf{m L})$ & $\mathbf{M B C}(\mathbf{m g} / \mathbf{m L})$ & $\begin{array}{c}\text { Zone of inhibition } \\
(\mathbf{m m})\end{array}$ \\
\hline HM95 & 10 & 5 & $22.00 \pm 1.00$ \\
\hline HM615 & 10 & 5 & $22.33 \pm 0.57$ \\
\hline HM251 & 10 & 5 & $22.67 \pm 0.57$ \\
\hline HM233 & 10 & 5 & $24.33 \pm 0.57$ \\
\hline
\end{tabular}

Table 2: Cytotoxic effect of Quercetin on Colorectal cell lines. Cell line $I_{50}$ Conc. $(\mu \mathrm{g} / \mathrm{mL})$

\begin{tabular}{cc}
$\begin{array}{c}\text { Cytotoxic effect of Quercetin on } \\
\text { Colorectal cell lines. }\end{array}$ & $\mathrm{IC}_{50}$ Conc. $(\mu \mathrm{g} / \mathrm{mL})$ \\
CaCO2 & 199 \\
COLO.205 & 121.1 \\
HT-29 & 5.81 \\
IEC-6 & 303.9 \\
\hline
\end{tabular}

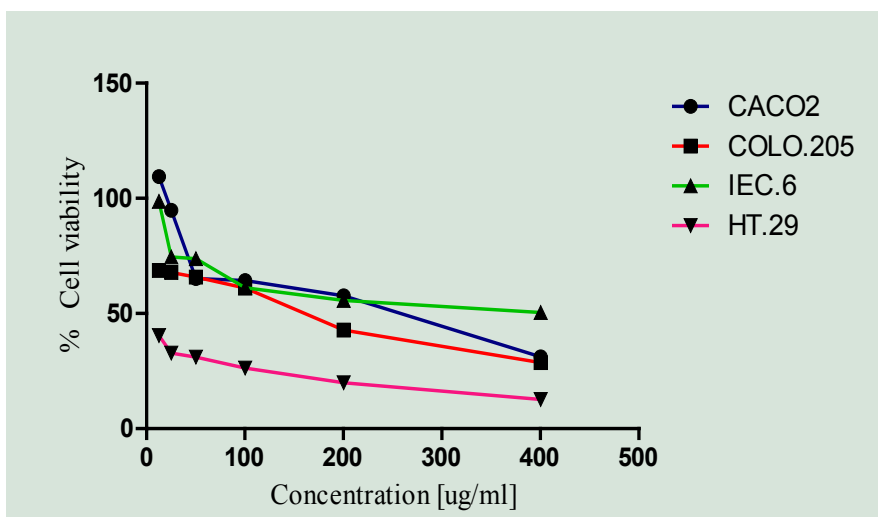

Figure 1: Percent cell viability: Quercetin against Colorectal cancer and normal cells

(Figure 1). The results are presented in Table 2 depicting $\mathrm{IC}_{50}$ values. ${ }^{[15]} \mathrm{IC}_{50}$ value was obtained to assess its inhibitory concentration that causes $50 \%$ cell viability. Previous studies suggest high toxic effect of quercetin against cancer cells, accompanied with little or no side effects or harm to normal cells. ${ }^{[16]}$ Our results are in agreement with previous claims regarding cytotoxic effect of quercetin.

\section{CONCLUSION}

Antibacterial activity of Quercetin was found against the bacterial isolates from CD and UC patients used in the study. Cytotoxity was observed against colorectal cancer cells with minimal effect on normal cells. However, further investigations are required to understand its precise mechanism.

\section{ACKNOWLEDGEMENT}

The authors are thankful to Prof. Barry J Campbell (Gastroenterology Research Unit, Institute of Translational Medicine, University of Liverpool, United Kingdom) for providing IBD strain through Material Transfer Agreement. The authors are also thankful to the KLE University, Belagavi for providing financial assistance towards the submitted research work.

\section{CONFLICT OF INTEREST}

The authors declare that there is no conflict of interest.

\section{ABBREVIATIONS}

AIEC: Adherent-invasive E. coli; IBD: Inflammatory bowel disease.

\section{REFERENCES}

1. Chang M, Chang L, Chang HM, Chang F. Intestinal and Extraintestinal Cancers Associated with Inflammatory Bowel Disease. Clinical Colorectal Cancer. 2018; 17(1):e29-37. 
2. Achkar JP. Inflammatory bowel disease, the American college of Gastroenterology. www.theportlandclinic.com/wpcontent/uploads/2014/05/tpc_inflammatoryboweldisease-achkar_10572.pdf

3. Kaulmann A, Bohn T. Bioactivity of Polyphenols: Preventive and Adjuvant Strategies toward Reducing Inflammatory Bowel Diseases-Promises, Perspectives and Pitfalls. Oxid Med Cell Longev. 2016;9346470.

4. Axelrad JE, Lichtiger S, Yajnik V. Inflammatory bowel disease and cancer: The role of inflammation, immunosuppression and cancer treatment. World J Gastroenterol. 2016;22(20):4794-801.

5. Martin HM, Campbell BJ, Hart CA, Mpofu C, Nayar M, Singh R, et al. 2004 Enhanced Escherichia coli adherence and invasion in Crohn's disease and colon cancer. Gastroenterology. 2004;127(1):80-93

6. Siew CN, Hai YS, Nima H, Fox EU, Whitney T, Eric IB, et al. Worldwide incidence and prevalence of inflammatory bowel disease in the $21^{\text {st }}$ century: A systematic review of population-based studies. The Lancet. 2017;390(10114):2769-78. 10.1016/S0140-6736 (17) 32448-0.

7. Kedia S, Ahuja V. Epidemiology of Inflammatory Bowel Disease in India: The Great Shift East. Inflamm Intest Dis. 2017;2(2):102-15.

8. Lin R, Piao M, Song Y. Dietary quercetin increases colonic microbial diversity and attenuates colitis severity in Citrobacter rodentium-infected mice. Front Microbiol. 2019;10:1092. https://doi.org/10.3389/fmicb.2019.01092

9. Dodda D, Chhajed R, Mishra J. Protective effect of quercetin against acetic acid induced inflammatory bowel disease (IBD) like symptoms in rats: Possible mor- phological and biochemical alterations. Pharmacological Reports. 2014;66:169 73.

10. Martin DA, Bolling BW. A review of the efficacy of dietary polyphenols in experimental models of inflammatory bowel diseases. Food Funct. 2015;6(6):1773-86.

11. Kumar V, Sharma N, Sourirajan A, Khosla PK. Comparative evaluation of antimicrobial and antioxidant potential of ethanolic extract and its fractions of bark and leaves of Terminalia arjuna from north-western Himalayas, India. Journal of Traditional and Complementary Medicine. 2018;8:100.

12. Quassinti L, Lupidi G, Maggi F, Sagratini G, Papa F, Vittori S, et al. Antioxidant and antiproliferative activity of Hypericum hircinum L. subsp. majus (Aiton) N Robson essential oil. Nat Prod Res: Formerly Natural Product Letters. 2013;27(10):862-8

13. Nitzan O, Elias M, Peretz A, Saliba W. Role of antibiotics for treatment of inflammatory bowel disease. World J Gastroenterol. 2016;22(3):1078-87.

14. Wang S, Yao J, Zhou B, Yang J, Chaudry MT, Wang M, et al. Bacteriostatic effect of quercetin as an antibiotic alternative in vivo and its antibacterial mechanism in vitro. J Food Prot. 2017;22:68-78.

15. Yang $L$, Liu Y, Wang M, Oian Y, Dong X, Gu H, Hisamitsu T. Quercetin-induced apoptosis of HT-29 colon cancer cells via inhibition of the Akt-CSN6-Myc signaling axis. Molecular Medicine Reports. 2016;14 4559-4566.

16. Rauf A, Imran M, Khan IA, Gilani SA, Mehmood Z, Mubarak MS. Anticancer potential of quercetin: A comprehensive review. Phytotherapy Research. 21092130. 2018:32(11):2109-30.

\section{GRAPHICAL ABSTRACT}

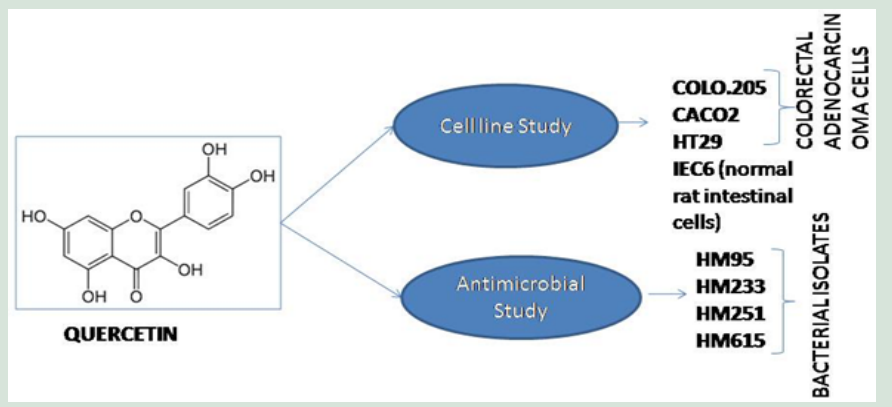

\section{SUMMARY}

- Quercetin is a polyphenol with wide pharmacological activities including beneficial effects in animal models of colitis. Its clinical efficacy for colitis is not well established. Results from earlier pre-clinical studies indicate an opportunity for developing anti-colitic polyphenol treatments.

- Quercetin was evaluated for its antimicrobial potential against clinical isolates of IBD patients (HM95, HM233, HM251, HM615). Cytotoxicity was determined against human colorectal adenocarcinoma cells (Caco2, COLO.205, HT.29), whereas, cytocompatibility against normal rat intestinal epithelial (IEC-6)

- This study provides an evidence for antibacterial activity of Quercetin against bacterial isolates from CD and UC patients. Cytotoxic potential of quercetin was also established. However, further investigations are required to understand its precise mechanism

\section{ABOUT AUTHORS}

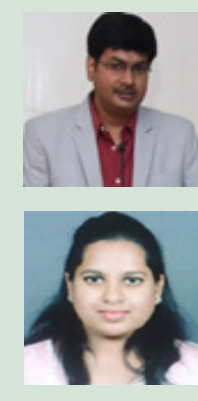

Dr. Sanjay Mishra: Presently working with KLE Academy of Higher Education and Research at BSRC and College of Pharmacy as Associate Professor and Research Scientist.

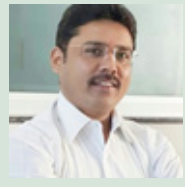

Dr. Sunil Satyappa Jalalpure: Associated with KLE Academy of Higher Education and Research at College of Pharmacy and BSRC as Principal and Professor.

Ms. Damita Cota: Working at KLE Academy of Higher Education and Research for her Doctoral research under supervision of Dr. Mishra.

History: Submission Date: 21-09-2020; Review Completed: 11-11-2020; Accepted Date: 08-01-2021

Cite this article: Mishra S, Cota D, Sunil SJ. Antibacterial Potential of Quercetin against IBD Bacterial Isolates and Cytotoxicity against Colorectal Cancer. Indian J Nat Prod. 2021;35(1):16-8. 